\title{
Pengembangan Jiwa Kewirausahaan Santri Melalui Ekonomi Kreatif dalam Menghadapi Tantangan Ekonomi Global (Studi di Pondok Pesantren Bahrul Maghfiroh Kota Malang)
}

\author{
Ahmad Muhtar Syarofi \\ Program Studi Hukum Ekonomi Syariah, Institut Agama Islam Al Qolam Malang \\ e-mail: Syairofysmart@yahoo.com
}

\begin{abstract}
ABSTRAK
Sekarang ini, dengan diberlakukannya Masyarakat Ekonomi Asian (MEA), kompetisi di dalam meningkatkan kualitas sumber daya manusia semakin meningkat. Hal ini menyajikan konsekuensi bagi setiap individu untuk terus mengembangkan dan meningkatkan kualitas mereka. Tidak terkecuali sumber daya manusia yang tinggal di pesantren. masyarakat Pondok Pesantren perlu meningkatkan kualitas untuk menjadi arena kompetitif dari dunia kerja. Oleh karena itu, pembinaan yang dilakukan dalam pesantren, harus mencerminkan dan memberikan pendidikan tentang pentingnya kemandirian, terutama di sektor keuangan. Penelitian ini bertujuan untuk menganalisis Kontribusi ekonomi kreatif untuk pengembangan semangat kewirausahaan dalam sistem pendidikan pesantren yang telah diterapkan pendidikan kewirausahaan sebagai sarana untuk melatih kemandirian finansial dari santri. Dengan menggunakan pendekatan fenomenologis, penelitian kualitatif ini dimulai dengan pengumpulan data melalui observasi dan dokumentasi untuk analisis nanti jadi menemukan beberapa peran ekonomi kreatif terhadap pengembangan semangat kewirausahaan di lingkungan pesantren. Kesimpulan dari penelitian ini adalah bahwa ekonomi kreatif memiliki beberapa peran penting dalam pengembangan semangat kewirausahaan di lingkungan pesantren. Ada: (1). Merangsang perilaku kreatif dan inovatif pada produk /layanan. (2). Mengeksplorasi dan mengasah keterampilan (3). Memberikan pengetahuan dengan metode learning by doing (4). Memberikan pelatihan tentang analisis SWOT (Strength, Weakness, Opportunity dan Threat). Penelitian ini terbatas pada analisis kontribusi ekonomi kreatif untuk pengembangan semangat kewirausahaan santri dalam menghadapi tantangan ekonomi global, khususnya di Pondok Pesantren Bahrul Maghfiroh Malang sehingga dapat diterapkan ke pesantren lainnya.
\end{abstract}

Kata kunci: Pengembangan, Ekonomi Kreatif, Kewirausahaan, Santri, Ekonomi Global 


\section{The Development of Sistrative Entrepreneurs Through Creative Economy in Dealing With The Global Economic Challenge (Study at Pondok Pesantren Bahrul Maghfiroh Malang)}

\section{ABSTRACT}

Now, with the enactment of the Asian Economic Community (AEC), competition in improving the quality of human resources is increasing. It presents the consequences for the individual to continue to develop and improve their quality. No exception of human resources who live in boarding schools. Pondok Pesantren community needs to improve the quality to become competitive arena of the world of work. Therefore, coaching is done in schools, should reflect and provide education about the importance of selfreliance, particularly in the financial sector. This study aimed to analyze the economic contribution of the creative for the development of entrepreneurial spirit in the pesantren education system which has been applied entrepreneurship education as a means to train the financial independence of students. By using a phenomenological approach, this qualitative study begins with the collection of data through observation and documentation for later analysis so find some creative economic role towards the development of entrepreneurship in boarding schools. The conclusion from this study is that the creative economy has several important roles in the development of the entrepreneurial spirit in boarding schools. There are: (1). Stimulate creative and innovative behavior on the product / service. (2). Explore and hone the skills (3). Providing knowledge with methods of learning by doing (4). Provide training on the SWOT analysis (Strength, Weakness, Opportunity and Threat). This study is limited to the analysis of economic contribution of the creative for the development of the entrepreneurial spirit of students in the face of global economic challenges, particularly at boarding school Bahrul Maghfiroh Malang so that it can be applied to other schools.

Keywords: Development, Creative Economy, Entrepreneurship, Pupils, Global Economy 


\section{PENDAHULUAN}

Berlakunya MEA (Masyarakat Ekonomi Asian) yang telah mulai berjalan pada 1 Januari 2016 silam dan tantangan ekonomi global, menghadirkan sebuah tantangan baru kepada masyarakat untuk bertindak ekonomis dan meningkatkan skill agar mempunyai tingkat daya saing yang tinggi. Dalam era perdagangan bebas, kita ditantang bukan hanya untuk mempersiapkan sumber daya manusia (SDM) yang siap bekerja, melainkan juga harus mampu mempersiapkan dan membuka lapangan kerja baru.

Kondisi yang terjadi di Indonesia beberapa periode ini, kita temukan bahwa masyarakat kita dididik untuk menjadi para pencari kerja. Dengan kondisi perekonomian yang tidak stabil, kemapanan dan keamanan dalam bekerja adalah tujuan utama, dan kemapanan tersebut didapat saat kita menjadi karyawan yang mendapat gaji bulanan yang tetap. Sekolah, kuliah, dan melamar pekerjaan sudah menjadi tradisi di negeri kita.

Hal ini berakhir dengan masalah pengangguran yang merupakan penyakit yang bersifat struktural dan kronis yang melanda seluruh negara berkembang. Hal ini disebabkan karena mereka yang mencari pekerjaan setiap tahun terus bertambah, sedangkan lapangan pekerjaan yang tersedia bagi mereka tidak mencukupi. Akibatnya, setiap tahun jumlah pengangguran terus meningkat. Hal ini dibuktikan dengan ramainya bursa lowongan kerja yang dijejali oleh para pencari lapangan pekerjaan.

Sistem ekonomi kreatif diyakini mampu menjadi solusi dalam mengatasi masalah tersebut dan sebagai alternatif dalam menghadapi tantangan ekonomi global yang akan menggeser sistem ekonomi yang telah berjalan seperti sistem ekonomi pertanian, ekonomi industri, dan ekonomi komunikasi. Indonesia yang kaya akan budaya dan berpenduduk besar mempunyai potensi yang sangat besar dalam pengembangan ekonomi kreatif.

Alvin Toffler dalam teorinya telah melakukan pembagian gelombang peradaban ekonomi kedalam tiga gelombang. Gelombang pertama adalah gelombang ekonomi pertanian. Kedua, gelombang ekonomi industri. Ketiga adalah gelombang ekonomi informasi. Kemudian diprediksikan gelombang keempat adalah gelombang ekonomi kreatif dengan berorientasi pada ide dan gagasan kreatif.

Pengembangan ekonomi kreatif Indonesia merupakan wujud optimisme serta luapan aspirasi untuk mendukung mewujudkan visi Indonesia yaitu menjadi negara yang maju. Didalamnya terdapat pemikiran, cita-cita, imajinasi, dan mimpi untuk menjadi masyarakat dengan kualitas hidup yang tinggi, sejahtera, dan kreatif.

Dalam ekonomi kreatif, SDM menjadi modal utama dalam sebuah pengembangan berawal dari gagasan, ide dan pemikiran, diharapkan SDM ini mampu menjadikan barang bernilai rendah menjadi barang yang bernilai tinggi dan berdaya jual. Profesi yang mengharuskan seseorang untuk memiliki daya kreativitas tinggi adalah wirausahawan. Maka pengembangan ekonomi kreatif ini secara tidak langsung mengarahkan dan mencoba untuk menciptakan wirausaha-wirausaha (entrepreneur) yang handal dalam bidangnya masing-masing . Daya kreativitas harus dilandasi oleh cara berpikir yang maju, penuh dengan gagasan-gagasan baru yang berbeda dengan produk yang sudah ada. Peluang pengembangan ekonomi kreatif telah merambah pada dunia pendidikan. Tidak luput juga dalam dunia pesantren. Banyak ditemukan pesantren-pesantren yang didalamnya menciptakan usaha (bisnis). 
Published Desember 2017

EKONOMIKAWAN : Jurnal Ilmu Ekonomi dan Studi Pembangunan

ISSN : 1693-7600 (Print), ISSN : 2598-0157 (Online), http://jurnal.umsu.ac.Id/index.php/ekawan

Pesantren adalah sebuah pendidikan tradisional yang para siswanya tinggal bersama dan belajar di bawah bimbingan guru yang lebih dikenal dengan sebutan kiai dan mempunyai asrama untuk tempat menginap santri. Santri tersebut berada dalam kompleks yang juga menyediakan masjid untuk beribadah, ruang untuk belajar, dan kegiatan keagamaan lainnya. Kompleks ini biasanya dikelilingi oleh tembok untuk dapat mengawasi keluar masuknya para santri sesuai dengan peraturan yang berlaku.

Pesantren juga dapat dipahami sebagai lembaga pendidikan dan pengajaran agama, umumnya dengan cara nonklasikal, di mana seorang kiai mengajarkan ilmu agama Islam kepada santri-santri berdasarkan kitab-kitab yang ditulis dalam bahasa Arab oleh Ulama Abad pertengahan, dan para santrinya biasanya tinggal di pondok (asrama) dalam pesantren tersebut.

Pesantren yang identik dengan ruh pendidikan Islam, yang identik pula didalamnya mengkaji tentang hukum-hukum Islam, kini telah berkembang mengikuti arus kontemporer dalam memberdayakan santri-santrinya. Peneliti mengangkat judul penelitian ini berangkat dari ketertarikan untuk memahami motivasi dan strategi apa yang dijadikan prinsip bagi suatu pesantren untuk mengembangkan ekonomi kreatif dilingkungannya

Penelitian ini juga hendak mengkaji praktik ekonomi kreatif, serta mengetahui seberapa besar kontribusi ekonomi kreatif di Pondok pesantren sebagai sarana pengembangan jiwa kewirausahaan para santri di Pondok Pesantren Bahrul Maghfiroh Kota malang yang di asuh oleh salah Seorang Pimpinan Pengusaha Santri Indonesia (HIPSI) wilayah Jawa timur yakni Kh. Gus Luqman Al Karim.

Pondok Pesantren Bahrul Maghfiroh Kota malang yang memiliki jumlah santri yang begitu banyak dan memiliki 28 cabang pondok pesantren yang tersebar di beberapa wilayah di Indonesia, walaupun pondok pesantern ini terbilang baru akan tetapi didalam perkembangannya sangat cepat sekali, seperti halnya pengembangan pendidikan maupun kewirausahaan seperti halnya butik, arsitektur dan jual beli properti, kerajinan, desain animasi, broadcasting, kuliner, penyiaran radio (www.andalus $911 \mathrm{fm} . \mathrm{com}$ ), pertelevisian (Batu TV). Lembaga bimbingan belajar, BMT Bahrul Maghfiroh, Perusahaan Air Mineral BMCI , perusahaan tempe dan tahu yang awalnya bersifat tradisional sehingga mendapatkan bantuan alat produksi modern dari luar negeri dan lain-lain.

Dari sekian banyaknya usaha yang dimiliki pondok pesantren bahrul Maghfiroh kota Malang akan tetapi kesemuanya dikelola oleh para santri. Di dalam hal pendidikan, pondok pesantren juga membebaskan seluruh biaya pendidikan para santri baik folmal maupun non formal seperti halnya Madrasah diniyah maupun yang bersekolah baik jenjang SD, SMP, SMA, maupun tingkat Perguruan tinggi, bahkan setiap tahunnya ada beberapa anak yang berprestasi, langsung disekolahkan sampai ke luar negeri, seperti halnya di Timur Tengah yang mana mereka setelah kembali dari belajar diharapkan mereka mampu mandiri sebagai ulama yang intelektual sehingga mampu mandiri di dalam menghadapi tantangan ekonomi global. Bahkan ibu Mentri Sosial Hj. Khofifah Indar Parawansa dan bapak Presiden ketika berkunjung beberapa waktu yang lalu merasa heran dan kagum atas kemajuan-kemajuan yang di miliki oleh Pesantren Maghfiroh Malang.

Berdasarkan hal tersebut diatas bagaimana kontribusi Pondok Pesantren Bahrul Maghfiroh Malang dalam mengembangkan ekonomi kreatif, serta bagaimana kontribusi ekonomi kreatif di pesantren Bahrul Maghfiroh Malang dalam mendorong semangat kewirausahaan para santri? 


\section{METODE}

Penelitian ini adalah penelitian kualitatif yaitu penelitian khusus objek yang tidak dapat diteliti secara statistik dan kuantitatif dengan pendekatan fenomenologis. Peneliti menggunakan metode analisis deskriptif yang dimaksudkan untuk menyajikan atau mendeskripsikan hasil temuan lapangan. Teknik pengumpulan data dari penelitian ini berupa observasi dan wawancara mendalam (depth interview).

Adapun data yang dikumpulkan adalah berupa: a) Data primer yang merupakan data yang diperoleh langsung dari penelitian. Data dikumpulkan dengan menyebarkan kuesioner kepada para santri yang menjadi pengurus kegiatan wirausaha yang ada di Pondok Pesantren Bahrul Maghfiroh b). Data sekunder adalah data yang diperoleh dari pihak organisasi atau dokumen yang masih berkaitan dengan tujuan penelitian. Adapun sumber datanya secara tidak langsung diperoleh dari Lingkungan Pondok Pesantren yang tergolong data sekunder adalah gambaran umum organisasi, jumlah karyawan, dan struktur organisasi dan buku-buku yang menunjang di dalam penelitian.

Populasi dan Sampel, a) Populasi ialah keseluruhan subyek penelitian. Apabila seseorang ingin meneliti semua elemen yang ada dalam wilayah penelitian, maka penelitiannya merupakan penelitian populasi. Studi atau penelitiannya juga disebut studi populasi atau studi sensus. Dalam penelitian ini yang menjadi populasi adalah para santri yang menjadi pengurus kegiatan wirausaha yang ada di Pondok Pesantren Bahrul Maghfiroh Malang. b) Sampel ialah Untuk menentukan jumlah sampel yang digunakan dalam penelitian adalah dengan menggunakan teknik sampling. Total sampling adalah teknik dimana jumlah sampel yang diambil sama dengan jumlah populasi. Menurut Arikunto (1996:120) apabila populasi yang diteliti < 100 maka sampel harus diambil semua, tetapi apabila populasi > dari 100 maka sampel yang diambil sebesar $10 \%-15 \%$ atau 20\% - 25\%. Jadi jumlah sampel yang diambil sama dengan jumlah populasi.

Untuk memperoleh data yang diperlukan sebagai bahan pokok dalam penelitian dilakukan penelitian secara langsung ke objek penelitian. Adapun cara yang digunakan adalah: a) wawancara, teknik pengumpulan data dengan tatap muka secara langsung dengan pihak Santri yang menjadi pengurus atau organisasi di Pesantren bahrul Maghfiroh Malang. b) kuesioner, teknik pengumpulan data dengan memberikan pertanyaan kepada pihak Santri yang menjadi pengurus atau organisasi di Pesantren bahrul Maghfiroh Malang guna mendapatkan jawaban yang berhubungan dengan penelitian.

\section{PEMBAHASAN}

Ekonomi Kreatif adalah penciptaan nilai tambah yang berbasis ide yang lahir dari kreatifivitas sumber daya manusia (orang kreatif) dan berbasis ilmu pengetahuan, termasuk warisan budaya dan teknologi.

Definisi lain menyebutkan Ekonomi kreatif pada hakikatnya adalah kegiatan ekonomi yang mengutamakan pada kreativitas berpikir untuk menciptakan sesuatu yang baru dan berbeda yang memiliki nilai dan bersifat komersial.

United Nation Conference on Trade and Development (UNCTAD) mendefinisikan ekonomi kreatif sebagai berikut: "Creativity in this context refers to the formulation of new ideas and to the application of these ideas to produce original works of art and cultural products, functional creation, observable in the way it contributes to entrepreneurship, fosters innovation, enhances productivity and promotes economic growth”. 
Istilah "Ekonomi Kreatif" mulai dikenal secara global sejak munculnya buku "The Creative Economy: How People Make Money from Ideas" (2001) oleh John Howkins. Howkins menyadari lahirnya gelombang ekonomi baru berbasis kreativitas setelah melihat pada tahun 1997 Amerika Serikat menghasilkan produk-produk Hak Kekayaan Intelektual (HKI) senilai 414 miliar dollar yang menjadikan HKI ekspor nomor 1 Amerika Serikat. Howkins dengan ringkas mendefinisikan ekonomi kreatif, yaitu "The creation of value as a result of idea".

Studi Ekonomi Kreatif telah dilakukan United Nations Conference on Trade and Development (UNCTAD) pada tahun 2010 mendefinisikan Ekonomi Kreatif sebagai: " $A n$ evolving concept based on creative assets potentially generating economic growth and development." Dengan penjelasan sebagai berikut :

a. Mendorong peningkatan pendapatan, penciptaan pekerjaan, dan pendapatan ekspor sekaligus mempromosikan kepedulian sosial, keragaman budaya, dan pengembangan manusia.

b. Menyertakan aspek sosial, budaya, dan ekonomi dalam pengembangan teknologi, Hak Kekayaan Intelektual, dan pariwisata.

c. Kumpulan aktivitas ekonomi berbasiskan pengetahuan dengan dimensi pengembangan dan keterhubungan lintas sektoral pada level ekonomi mikro dan makro secara keseluruhan.

d. Suatu pilihan strategi pengembangan yang membutuhkan tindakan lintas kementerian dan kebijakan yang inovatif dan multidisiplin.

e. Di jantung Ekonomi Kreatif terdapat Industri Kreatif.

Di Indonesia, ada 15 subsektor ekonomi kreatif yang dikembangkan, dari sebelumnya 12 subsektor. Adapun subsektor ekonomi kreatif yang dimaksud yakni arsitektur, desain, film, video dan fotografi, kuliner, kerajinan, mode, musik, serta penertiban dan percetakan. Selain itu termasuk permainan interaktif, periklanan, riset dan pengembangan, seni rupa, seni pertunjukan, teknologi informasi, serta televisi dan radio.

Menurut Departemen Perdagangan (2007), ada beberapa arah dari pengembangan industri kreatif ini, seperti pengembangan yang lebih menitikberatkan pada industri berbasis: (1) lapangan usaha kreatif dan budaya (creative cultural industry); (2) lapangan usaha kreatif (creative industry), atau (3) Hak Kekayaan Intelektual seperti hak cipta (copyright industry).

\section{Entrepreneurship}

Entrepreneurship berasal dari bahasa Prancis yaitu 'entreprende' yang berarti petualang, pencipta dan pengelola usaha. Istilah ini diperkenalkan pertama kali oleh Richard Cantillon (1755). Istilah ini semakin populer setelah digunakan oleh pakar ekonomi J.B Say (1803) untuk menggambarkan para pengusaha yang mampu memindahkan sumber daya ekonomis dari tingkat produktivitas rendah ke tingkat yang lebih tinggi serta menghasilkan lebih banyak lagi.

Pendapat lain tentang entrepreneurship menurut Zimmerer yaitu suatu proses penerapan kreativitas dan inovasi dalam memecahkan persoalan dan menemukan peluang untuk memperbaiki kehidupan (usaha). 
Definisi lain mengenai entrepreneurship merupakan sebuah proses penciptaan sesuatu yang berbeda nilainya dengan menggunakan usaha dan waktu yang diperlukan, memikul risiko financial, psikologi dan sosial yang menyertainya, serta menerima balas jasa financial dan kepuasan pribadi.

Instruksi Presiden Nomor 4, 30 Juni 1995 Tentang Gerakan Nasional Memasyarakatkan dan Membudayakan Kewirausaan disebutkan, bahwasanya; " Kewirausahaan (entrepreneurship) adalah semangat, sikap, perilaku dan kemampuan seseorang dalam menangani usaha dan kegiatan yang mengarah pada upaya mencari, menciptakan, menerapkan cara kerja, teknologi dan produksi baru dengan meningkatkan efisiensi dalam rangka memberikan pelayanan yang lebih baik dan atau memperoleh keuntungan yang lebih besar.

Sedangkan kata entrepreneur (pelaku entrepreneurship) dalam bahasa Indonesia merupakan gabungan dari wira (gagah, berani, perkasa) dan usaha (bisnis) sehingga istilah entrepreneur dapat diartikan sebagai orang yang berani atau perkasa dalam usaha/bisnis .

Pengertian lain dari entrepreneur adalah an owner or manager of a business enterprise who makes money through risk and initiative. Artinya, pemilik atau manager sebuah perusahaan bisnis yang menghasilkan keuntungan melalui pengambilan risiko dan tindakan inisiatif.

Secara sederhana arti wirausaha (entrepreneur) adalah orang yang berjiwa berani mengambil risiko untuk membuka usaha dalam berbagai kesempatan. Berjiwa berani mengambil risiko artinya bermental mandiri dan berani memulai usaha, tanpa diliputi rasa takut atau cemas sekalipun dalam kondisi tidak pasti.

Terdapat beberapa tipe utama dari wirausaha, antara lain :

1. Wirausaha Ahli (Craftman)

Wirausaha ahli atau seorang penemu memiliki suatu ide yang ingin mengembangkan proses produksi sistem produksi, dan sebagainya. Wirausaha ahli ini biasanya seseorang yang bekerja pada sebuah perusahaan besar kemudian memutuskan untuk keluar sebagai pegawai dan memulai bisnisnya sendiri.

2. The Promoter

The promoter adalah seorang individu yang tadinya mempunyai latar belakang pekerjaan sebagai sales atau bidang marketing yang kemudian mengembangkan perusahaan sendiri.

3. General Manager

General manajer adalah seorang individu yang ideal yang secara sukses bekerja pada sebuah perusahaan, dia banyak menguasai keahlian bidang produksi, pemasaran, permodalan dan pengawasan

Ciputra, dalam bukunya Entrepreneurship Mengubah Masa Depan Bangsa, membagi entrepreneur kedalam empat kategori. Yaitu :

a. Business Entrepreneur

1) Owner entrepreneur adalah para pencipta dan pemilik bisnis

2) Professional entrepreneur adalah orang-orang yang memiliki daya wirausaha namun mempraktikannya di perusahaan milik orang lain 
Published Desember 2017

EKONOMIKAWAN : Jurnal Ilmu Ekonomi dan Studi Pembangunan

ISSN : 1693-7600 (Print), ISSN : 2598-0157 (Online), http://jurnal.umsu.ac.id/index.php/ekawan

3) Government Entrepreneur

Seorang atau kelompok orang yang memimpin serta mengelola lembaga negara atau instansi pemerintahan dengan jiwa dan kecakapan wirausaha. Sebagai contoh adalah Lee Kuan Yew, mantan Perdana Menteri Singapura, ia adalah seorang pemimpin yang mengelola dan menumbuhkan Singapura dengan jiwa dan kecakapan wirausaha.

4) Social Entrepreneur

Yaitu para pendiri organisasi-organisasi sosial kelas dunia yang menghimpun dana masyarakat untuk melaksanakan tugas sosial yang mereka yakini.

b. Academic Entrepreneur

Ini menggambarkan akademisi yang megajar atau mengelola lembaga pendidikan dengan pola dan gaya entrepreneur sambil tetap menjaga tujuan mulia pendidikan.

\section{Profil Pondok Pesantren Bahrul Maghfiroh}

Pondok Pesantren Bahrul Maghfiroh Kota Malang ber-alamatkan di Jalan Joyo Agung no 2, desa Tlogomas, kec lowokwaru Kota Malang yang berdiri tahun 1997 diatas Luas tanah $3000 \mathrm{~m}^{2}$. Pondok Pesantren Bahrul Maghfiroh Kota malang pada awalnya memiliki jumlah santri yang sedikit tetapi karena perjuangan dan sosok karisma Pengasuhnya yang tinggi sehingga sekarang beliau memiliki jumlah santri yang begitu banyak dan memiliki 28 cabang pondok pesantren yang tersebar di beberapa wilayah di indonesia, dan di luar negeri.

Walaupun pondok pesantern Bahrul Maghfiroh terbilang baru akan tetapi didalam perkembangannya sangat cepat sekali, seperti halnya pengembangan pendidikan maupun kewirausahaan seperti halnya: Butik, Arsitektur dan Jual beli Properti, Kerajinan, Desain Animasi, Broadcasting, kuliner, Penyiaran Radio (www.andalus911fm.com ), pertelevisian (Batu TV). Lembaga bimbingan belajar, BMT Bahrul Maghfiroh, Perusahaan Air Mineral BMCI , Perusahaan tempe dan tahu yang awalnya bersifat Tradisional Sehingga mendapatkan bantuan alat produksi modern dari luar negeri dan lain-lain.

Dari sekian banyaknya usaha yang dimiliki pondok pesantren bahrul Maghfiroh Kota Malang akan tetapi kesemuanya dikelola oleh para santri. Di dalam hal Pendidikan, pondok pesantren juga membebaskan seluruh biaya pendidikan para santri baik folmal maupun Non Formal seperti halnya Madrasah diniyah maupun yang bersekolah baik jenjang SD, SMP, SMA, maupun Tingkat Perguruan tinggi, bahkan Setiap tahunnya ada beberapa anak yang berprestasi, langsung di sekolahkan sampai keluar negeri, seperti halnya ditimur Tengah yang mana mereka setelah kembali dari belajar diharapkan mereka mampu mandiri sebagai ulama yang intelektual sehingga mampu mandiri di dalam menghadapi tantangan Ekonomi Global. Bahkan Ibu mentri Sosial $\mathrm{Hj}$ Khofifah Indar Parawansa dan Bapak Presiden Ketika Berkunjung beberapa waktu yang lalu merasa heran dan kagum atas kemajuan-kemajuan yang di miliki oleh Pesantren Maghfiroh Malang.

Pendirian Pondok Pesantren Bahrul Maghfiroh Malang mempunyai tujuan tujuan mendidik santri agar menjadi manusia muslim selaku kader-kader Ulama dan Mubaligh yang berjiwa, ikhlas, tabah, tangguh, mandiri dalam mengamalkan ajaran Islam secara utuh dan dinamis, serta siap bertugas melayani dan mengasuh masyarakat. 
Penyelenggaraan pendidikan keagamaan bertujuan untuk menghasilkan lulusan yang beriman dan bertaqwa kepada Tuhan Yang Maha Esa, berakhlak mulia, tempat persemaian dan mengembangkan potensi kader-kader ulama', tokoh masyarakat dan wahana dalam menggembleng generasi muda dalam pemberdayaan dan pengembangan keilmuan khususnya yang bersifat keagamaan. Yang meliputi Ilmu Al-Qur'an, hadist, Fiqh, Nahwu dan Shorof, dan cabang keilmuan lainnya di bidang agama. Hingga nanti menjadi anggota masyarakat yang bertanggungjawab dengan keilmuuan yang telah diperolehnya selam di pesantren.

Penyelenggaraan pendidikan umum atau pendidikan formal bertujuan memberikan jawaban akan pentingnya legalitas keilmuan yang menghasilkan lulusan yang beriman dan bertaqwa kepada Tuhan Yang Maha Esa, berakhlak mulia, mengembangkan santri agar menjadi masyarakat yang bertanggung jawab dan demokratis, mengetahui dasar - dasar ilmu pengetahuan dan teknologi, memiliki etos dan budaya kerja, dan mengikuti pendidikan lebih lanjut. Sehingga dalam mewujudkan hal itu, masing-masing program studi perlu adanya visi dan misi yang jelas.

Visi : Terwujudnya manusia yang bertaqwa, berjiwa mukhlis, berakhlaqul karimah, berilmu, kreatif, aktif, semangat, cakap, berguna bagi agama, bangsa dan Negara".

Misi : Sampai pada perkembangan berikutnya, pesantren masih tetap menunjukkan fungsinya sebagai lembaga pengajaran dan pendidikan, lembaga dakwah dan pengkaderan ulama', sebagai lembaga pelayanan, pengarahan, bimbingan dan pengembangan kemasyarakatan, serta sebagai lembaga perjuangan. Mewujudkan manusia yang beriman dan bertaqwa melalui ajaran agama Islam berhaluan Ahlusunah wal jamaah, meningkatkan manusia yang berbudi luhur, berdisiplin, berhati lembut, bertanggung jawab, bijaksana, bekerja keras dan beradab, memadukan pembelajaran model pesantren salaf dengan sekolah, pendidikan agama dengan pendidikan umum, Meningkatkan ketrampilan baik dibidang Imtaq maupun IPTEK, Meningkatkan kesehatan jasmani dan rohani melalui bidang olahraga, kesehatan dan keagamaan, Mewujudkan insan yang mandiri siap melanjutkan ke jenjang sekolah yang lebih tinggi dan siap masuk dunia usaha dan kerja, Menumbuhkan dan mendorong keunggulan dalam penerapan ilmu pengetahuan umum dan ilmu pengetahuan agama.

\section{KESIMPULAN}

Dari penelitian ini adalah bahwa ekonomi kreatif memiliki beberapa peran penting dalam pengembangan semangat kewirausahaan di lingkungan pesantren. Ada: (1). Merangsang perilaku kreatif dan inovatif pada produk / layanan. (2). Mengeksplorasi dan mengasah keterampilan (3). Memberikan pengetahuan dengan metode learning by doing (4). Memberikan pelatihan tentang analisis SWOT (Strength, Weakness, Opportunity dan Threat). Pesantren yang identik dengan ruh pendidikan Islam, yang identik pula didalamnya mengkaji tentang hukum-hukum Islam, kini telah berkembang mengikuti arus kontemporer dalam memberdayakan santri-santrinya sehingga mampu untuk menghadapi perkembangan zaman yang semakin maju. 


\section{DAFTAR PUSTAKA}

Anggraini, Nenny, 2008, "Industri Kreatif", Jurnal Ekonomi Vol.XIII No. 3 Desember.

Barnawi \& M. Arifin, 2012, Schoolpreneurship : Membangkitkan Jiwa dan Sikap Kewirausahaan Siswa, Jogjakarta : Ar-Ruzz Media

Basrowi \& Suwandi, 2008, Memahami Penelitan Kualitatif, Jakarta : Rineka Cipta

Ciputra, 2008, Entrepreneurship Mengubah Masa Depan Bangsa ,Jakarta : PT Alex Media Komputindo Departemen Agama Republik Indonesia.

Departemen Perdagangan, 2007, Cetak Biru Pengembangan Ekonomi Kreatif Indonesia, Jakarta : Departemen Perdagangan.

Dhofier, Zamakhsyari, 1983. Tradisi Pesantren Studi tentang Pandangan Hidup Kyai, Jakarta : LP3S.

Ghony , M. Djunaidi \& Fauzan Almanshur, 2012, Metodologi Penelitian Kualitatif, Yogyakarta : Ar-Ruzz Media.

Hakim Nasution, Arman, dkk,200, Entrepreneurship, Membangun Spirit Teknopreneurship, Yogyakarta : ANDI.

Indonesia Kreatif, 2013, dalam http://indonesiakreatif.net/creative-economy/what-is/whatis/\#di9il8WCqXpePgH1.99

J. Moleong, Lexy,2014, Metodologi Penelitian Kualitatif, Bandung : Anggota Ikapi.

Kasmir, 2013, Kewirausaan, Jakarta : Raja Grafindo Persada.

Kementrian Pariwisata dan Ekonomi Kreatif RI, 2015-2019. Ekonomi Kreatif : Rencana Aksi Jangka Menengah .

Majalah Kina, Karya Indonesia Edisi 3-2011.

Prasodjo, Sudjono, 1982. Profil Pesantren, Jakarta: LP3S.

Suherman, Eman, 2008, Desain Pembelajaran Kewirausaaan, Bandung :Alfabeta.

Suryana, 2013, Ekonomi Kreatif (Ekonomi Baru : Mengubah Ide dan Menciptakan Peluang) Jakarta : Salemba Empat

Suryana,Yuyus dan Kartib Bayu, 2010, Kewirausahaan :Pendekatan Karakteristik Wirausahawan Sukses, Jakarta : Kencana Prenada Media Group.

UNCTAD, 2008, Summary Creatif EconomicReport, United Nation : USA.

Winarno, 2011, Pengembangan Sikap Entrepreneurship dan Intrapreneurship, Jakarta : Indeks. 